\title{
David Rieff, In Praise of Forgetting: Historical Memory and Its Ironies. New Haven, CT: Yale University Press, 2016, 160 pp.
}

\section{In Praise of Forgetting and the Historical Memory of the Spanish Civil War}

"Those who cannot remember the past are condemned to repeat it". This phrase has become so engrained in both academic and popular culture that today it seems a cliché. David Rieff in his penetrating book, In Praise of Forgetting: Historical Memory and Its Ironies challenges this conventional wisdom with theoretical, political and practical engagement. ${ }^{1}$

Indeed Rieff's counter arguments to Santayana's famous dictum about the consequences of historical oblivion are troubling. The understanding of how individuals, nations, and segments of society cope with, manipulate, or apprehend the past is precisely what Rieff in this short, albeit far reaching, book has addressed. By far reaching I mean global. Rieff deals geographically with all the continents of the planet, not just the mythical "West", as is often the reference point of theoreticians of history. His historical frame reaches as far as before the Common Era, i.e. the grand memories of the Su-Han War in China and the Battle of Salamis, a move which might be seen as a transgression in the Academy in our need for specificity. Yet it is clear in his analysis that human beings love to celebrate and/or lament their pasts. Perhaps because Rieff is not an academic, his sweeping statements are not easily dismissed, for he is addressing himself to issues dealing with the (over)reading of history, and offers telling examples from all over the place - literally.

His conclusion is just what we don't want to hear: forgetting may be a good thing in some cases, in the light of all the turmoil, suffering, destruction, pain, death, and a long etc., that remembering has forged. He takes on Santayana's dictum through discussions of Tzevetan Todorov, Avishai Margalit, Paul Ricoeur, Eric Hobsbawm, Yosef Hayim Youshilada, Ernest Renan, Ernest Gellner, and Pierre Nora with his oft-referenced idea of lieux de memoirs ("places of memory"). All of these thinkers in various iterations and qualifications argue for the duty of historical memory. To recall the past as in the familiar phrase "lest we forget..." is for Rieff a "far too celebrated" activity; it is a "false injunction" (p. 58). As he elucidates in his first chapter, this phrase comes from the refrain of a poem, "Recessional" by none other than Rudyard Kipling whose glorifications of the British Empire need little deliberation. But we would do well to ask: what precisely is it that we mustn't forget? And what exactly is the good of remembering? Indeed Santayana's dictum begs for a series of rejoinders: When should we remember and when should we forget? What is it to remember? Is it possible to remember collectively? Is memory willful? Selective?

\footnotetext{
${ }^{1}$ David Rieff, In Praise of Forgetting: Historical Memory and Its Ironies (New Haven, CT: Yale University Press, 2016).
} 
Collective memory, unlike individual memory, is not a tangible phenomenon, there is nothing in our brain that designates it. Rather memory in the collective sense is more clearly connected to narrative, that is, its roots dwell in the realm of fiction and imagination. Equally important is oblivion - forgetting the past, for Santayana, is to repeat it, and the repetition will have dire consequences. But again, in his philosophical work out of which this phrase comes, Life of Reason: Or the Phases of Human Progress, he does not refer to the past in collective terms; the past for him in this work is something that individuals either remember or forget. ${ }^{2}$

Admittedly, there is something of a tongue-in-cheek tone (perhaps unwitting) in this book, because Rieff does not "praise" forgetting outright; he never declares a need for the end of historical memory. As a social critic and as a worker in an NGO that tried to deal directly with the consequences of the Bosnian War, Rieff does not dismiss its remembrance, rather he questions its uses and abuses. I would go further: considering the vapidness with which some commentators, historians, and concerned members of civil society use Santayana in position papers, manifestos, honorary degree speeches, etc., the phrase comes off as something of an aphorism, like the very history and continuity not remembered - a poem, a haiku, a wink of the eye in the spirit of Nietzsche.

Quoting Paul Ricoeur, Rieff sets up what I see as his main argument: "We must remember because remembering is a moral duty. We owe a debt to the victims..." But however counterintuitive my argument may seem, and however much one honors the moral seriousness of those like Ricoeur (and others) who have advanced various, and not entirely congruent versions of this position, what if they are wrong? What if, over the long term, forgetfulness is inevitable, while even in the comparatively short term the memory of an instance of radical evil, up to and including the Shoah itself, does nothing to protect society from future instances of it? And what if, instead of heralding the end of meaning, a decent measure of communal forgetting is actually the sine qua non of a peaceful and decent society, while remembering is the politically, socially, and morally risky pursuit? (pp. 56-7).

That "what if?" should give us all pause. It's something both as academics and as members of civil society we seem unwilling to consider. These questions lead one to ponder the "good" of collective memory in more global terms than I am used to as I explore the vexing presence of the Spanish Civil War in the collective memory (if there is such a thing) of Spain. In the many essays, novels, stories, films, and opinion pieces in El País (and virtually every other Spanish news outlet, including TV and the internet), with some notable exceptions, rarely do we find an attempt to come to terms with Spanish collective memory of the Civil War in universal or philosophical terms. I am not asking Spanish citizens and writers to become turgid and impenetrable philosophers, I ask instead that we focus on the issue with a more panoramic lens. Notwithstanding Manuel Fraga Iribarne and the Spanish ministry of tourism during the Franco regime who coined the phrase España es diferente ("Spain is different"), the Iberian Peninsula may have its differences, but it is not "exceptional". Rieff himself points to Spain and the Spanish Civil War in general terms; for

\footnotetext{
${ }^{2}$ George Santayana, Live of Reason or Phases of Human Progress (New York: Scribners, 1920), 284.
} 
that world historical phenomenon is a telling manifestation of the good words he has for oblivion. This book and another essay appearing in the Guardian, something of an introduction to Forgetting titled "The Cult of Memory: When History Does More Harm Than Good", emerges from what he sees as memory's impediments for the creation of peace. ${ }^{3}$ Immediately after the death of Franco, he argues, opening up the historical record to a counter-reading would have been akin to opening a bloody wound.

In his first chapter Rieff discusses Kipling's famous poem "Recessional" with its refrain, "lest we forget", arguing that inflaming nationalist sentiments will often lead only to historical obsession, more conflict, disharmony, and all kinds of misery that people have experienced directly and virtually. Poetry, literature, fiction, as Benedict Anderson has put forth in his Imagined Communities, serves that purpose. ${ }^{4}$ Clearly the Spanish conflict of the 30s fits into this scenario. Its historical interpretation as a just crusade against what Franco saw as the judeo-communist-masonic conspiracy was used as a strategy for him to stay in power. The 30 years of peace he declared in 1969 was anything but peaceful; the Civil War was kept very much alive in the historical hearts and minds of Spanish people to justify censorship, political incarcerations, and abuse of power. For Franco the duty to remember ironically kept the peace. But those of us who know the parlance of anti-war activists can see Franco's contradiction in historical terms, i.e. that "negative peace" - should be distinguished from "positive peace", that without justice there can be no peace. In many ways one could argue that Franco was a proponent of, "lest we forget."

The willful forgetfulness came later when Franco died while still at the helm of Spanish society. It was what many Spanish historians (along with the communications industries and members of Spanish civil society) have called the Pacto de Olvido ("The Pact of Forgetting"). Rieff uses this "pacto" as something of an exception (a positive one) to a more pervasive call to arms of remembrance that he sees in Israel-Palestine and most of the Middle East, Ireland, and the Balkans, an area whose misery Rieff has picked apart both intellectually and experientially. Spanish people, as opposed to the Irish, Israelis, Palestinians, Bosnians, etc., were obligated by circumstances to relive their civil-war past well after things fell apart. At the time of Franco's death - unlike, say, the death of Tito in the former Yugoslavia, there was what came to be known as the peaceful transition from dictatorship to democracy -, a transition whose amnesty granted to those anti-Francoists in exile or in prison went only as far as a new tolerance to the other side while not as far as prosecution of those who had committed atrocities both to attain and maintain dictatorial power. In one of the many ironies of reality known to history, some of those who would arguably be considered war criminals were at the helm of orchestrating the transition.

But transition from what to what?, asked many on the left who sought historical justice. It was a rhetorical question whose answer they begged was that Franco's legacy had

\footnotetext{
${ }^{3}$ David Rieff, "The Cult of Memory: When History Does More Harm Than Good", The Guardian, March 2, 1916.

${ }^{4}$ Benedict Anderson, Imagined Communities: Reflections on the Origin and Spread of Nationalism (New York: Verso, 1988).
} 
continued with the trappings of a new democracy. In this willful oblivion there were no Nuremberg trials, because if there had been, the judges of the misdeeds would have been among those who had committed them. In fact the overall consequences of this so called transition were felt far more in the realm of culture than politics: the birth of new communications outlets - most notably, El País -, open anticlericalism in the form of mockery and sacrilege, liberalization of divorce laws, pornography, and of course, Almodóvar. As I continue to ponder what Rieff's kudos to the Spanish transition mean, I am compelled to add that these cultural changes also have as much to do with individual remembrance as with collective memory. Virtually every Spanish member of my generation born around the time of the end of the War might recall how she-he was beaten by a priest or nun for thinking of or partaking in "impure" acts. The academy award winning film Spotlight has made an impact in Spain, not because it depicts something Spaniards never talk about - there have been countless films, novels and stories in Spain about similar cases - but because they are intrigued by the fact that these abuses happened in a country known for its religious freedom.

As Rieff goes on to offer his views of Spanish historical memory, he describes the activities and successes of one of Spain's most well-known political-social figures, Baltazar Garzón, the magistrate who famously issued a warrant for the arrest of Augusto Pinochet for murder and torture of Spanish citizens. But in Spain his prominence has more to do with his work on behalf of the "Association For the Recuperation of Historical Memory", a group of lawyers, intellectuals, family members of victims, and citizens representing many parts of Spanish society, whose aim was and remains to revive the memory of victims of Francoist repression: exhumation of graves, financial retribution to victims, public works of remembrance in the form of new statues or commemorations, loosening citizenship restrictions for the children and grandchildren of exiles and political prisoners. According to Rieff, this seems to be working (within the framework of the possible) mostly because it has come into practice from the vantage point of historical distance: " $211^{\text {st }}$ century Spain no longer needs the "pacto de olvido"” (p. 125). In other words, contrary to those who declaimed the impunity of killers, torturers, and opportunists who were either proactive in committing atrocities or indifferent to them, Rieff suggests that this case of enforced historical forgetting had a good or useful outcome, particularly in comparison to the outpouring of partisan historical remembrance that we see today in Palestine-Israel, the Balkans in the nineties, Ireland (throughout its history), Libya still, the Sri Lankan civil war, and the list goes on. Thus in Spain, mercifully, we have a hopeful exception to the rule.

But today there are Spaniards who disagree. For some, like José Colmeiro in his pioneering work, Memoria histórica e identidad nacional, the pact to forget remains a moral travesty, since the reconciliation meant there would be no justice for the many victims of Franco's oppression "forgotten" by the supposedly democratic Spanish government and by the world. ${ }^{5}$ Moreover some have extended this argument by attributing Spain's present woes to the policy of forgetting. Authoritarian and hierarchical tendencies especially in rural Andalusia where poverty is rampant and unemployment is over thirty

\footnotetext{
${ }^{5}$ José Colmeiro, Memoria histórica e identidad nacional (Barcelona: Anthropos, 2005).
} 
percent -, political-economic abuse of power and corruption - all of this, some have argued, find their origin in the willful "dismemory" of the war. There is no denying that some of these arguments have merit, but what do we do about the past?

A prominent historian of the Spanish transition to democracy, Santos Juliá, echoing Rieff's felicitations of strategic forgetfulness, was castigated by some intellectuals and common citizens for what was read as an apology of the pacto de olvido. In his intellectual autobiography Elogio de la historia en tiempos de memoria ("In Praise of History in Times of Memory") ${ }^{6}$ as well as his Victimas de la guerra (Victims of the War) ${ }^{7}$ he addresses himself to many of the issues treated in Rieff's book by putting forth the idea that forgetting at times is a strategy to achieve peace and democracy. At one point in Elogio Juliá stresses how his views have been misinterpreted as promoting "collective dismemory, amnesia, and silence", as he has been accused of being "memory's foe and oblivion's defender" (p. 128). But his position, he declares emphatically in this autobiography, has never been to place forgetting on a pedestal, rather, much like Rieff, he argues that reremembering the conflict immediately after the death of the one most responsible for the dire consequences, would amount to reliving it, and as such the necessary work of creating viable and peaceful democracies would not move forward. His turn of phrase is echar al olvido ("cast into oblivion"), a beneficial gesture different from olvidar (to forget). Casting something off implies that it might be possible to recuperate at some other time, whereas, forgetting allows it to disappear. In a curious way, I suspect Rieff with all his qualifications to the benefits of the act of forgetting, might agree.

However, Juliá does not stop at a justification for his previous positions. Again in a language that parallels Rieff's contentions, he offers a compelling disquisition on the nature and motivations of the recent emphasis on memory to the detriment of history. He sees an acutely risky tendency these days ("times of memory") to explain history according to things that supposedly did not happen but should have. The historian or the "interpreter" of events who relies exclusively on memory prefers not to explain things that did happen, and opts to tell us why they shouldn't have. ${ }^{8}$ In one chapter he discusses the "rise of memory": La memoria cotiza al alza ("Memory Contributes to a Rise [in the Stock Market]"). "Alza" is a play on words between the notion of a general increase in any phenomenon and the rise of the stock market, thereby disparaging the over-emphasis on memories. Memory studies emerge from a popular (and marketable) late twentieth and early twenty-first-century distrust of history. Admittedly, from this urge to switch the focus from the object of study to the speaking and feeling subject good questions emerge: who writes history, for what reasons, what are the consequences, and how is it tailored? But its fashion, its trendiness, in these "times of memory" often lead to distortions and simplicities. Thus Juliá is critical of some historians, as well as those engaged in "cultural studies", for whom memory is more reliable than conventional history because the former comes from the member of a group

\footnotetext{
${ }^{6}$ Santos Juliá, Elogio de la historia en tiempos de memoria (Madrid: Pons-Fundación Alfonso Escudero, 2011).

${ }^{7}$ Santos Juliá, Víctimas de la guerra (Madrid: Temas de Hoy, 2006).

${ }^{8}$ Santos Juliá, Elogio de la historia, 129.
} 
that has suffered political, social, economic injustice; it is the voice of one who speaks the group's experience, and in so doing gives insights into the ways identity, gender, class, and nationality or ethnicity temper and inform collective consciousness. These are the narratives that often counter or question the historical records. Not that we shouldn't consider these testimonies, says Juliá, but privileging them to the detriment of history in the traditional disciplinary sense leads to distortions.

Of the countless works (novels, essays, films, web sites) in the last three or so decades created by Spaniards on the so called "historical memory of the Spanish Civil War", perhaps most relevant to both our discussion is Javier Cerca's various contributions to the issue. Well known is his novel, or relato real ("real story"), Soldados de Salamina, and the film adaptation by David Trueba with the same title. ${ }^{10}$ First published in 2001, the novel gave rise to much discussion (mostly praise with some criticism) because it presented something not many of us "democratically inclined" Spaniards were not used to. It dealt with the life of a falangist poet who became a high-ranking official in the Franco regime, Rafael Sánchez Mazas. Cerca's treatment of this right-wing poet was, God forbid, not entirely negative.

Many of the films and narratives dealing with the war and its aftermath manifest a tendency to recreate and perceive the events with an eye and inclination toward the ghostly: Espinazo del diablo, Ay Carmela, Lápiz del carpintero, Laberinto del fauno, among others (I would argue that even La voz dormida portrays events that come back to haunt). Cercas shuns this tendency while at the same time he does not resort to the narrative inclinations of the previous generation of Civil War writers such as Max Aub, Ramón Sender, Arturo Barea, Sánchez Barbudo, and José María Gironella, whose experience of the war was direct and whose recreations adhered to the conventions of the $19^{\text {th }}$ century historical novel. In my opinion as a literary critic of this period, Cercas has forged something of a new genre, or sub-genre of the novel by doing away with any pretention (at least on the surface) of creating a fiction. First his narrative voice is at once transparent and self-conscious; he speaks for himself, Javier Cercas, a man whose family is riddled (or cursed) with people who supported Franco, and Javier, the writer-character, wants to get to the bottom of it using both the memory of those who lived the experience and "real" history-documents, archives, letters, photos, news print.

Javier is the citizen-historian impatient with notions of trauma and extraterrestrial figures that have informed our understanding of the war in the 90s and the first decades of the $21^{\text {st }}$ century. Indeed Cercas still believes in the value of history, and when his historian protagonist investigates something in the "historical memory" of another character that he finds dubious he offers his reading (or several other readings) of what really happened or what could have happened. The discourses of history and novel have rarely been as indistinguishable. Is there a notion in his writing of a "duty to remember" as in the majority of the theoreticians of collective memory in the light (or darkness) of the atrocities of the

\footnotetext{
${ }^{9}$ Javier Cercas, Soldados de Salamina (Barcelona: Tusquets, 2001).

${ }^{10}$ Soldados de Salamina, directed by David Trueba (Buenos Aires, Primer Plano, 2003).
} 
$20^{\text {th }}$ century and before? I would say perhaps, but what stands out is more a duty to understand, to "get it right." In a passage from a recent novel, something of a sequel to Soldados de Salamina (proof that the Civil War continues to obsess him, not haunt him), El monarca de las sombras ("King of the Shadows") 11 about the short life of his great uncle, Manuel Mena, who died fighting for Franco, Cercas lays bare the intention of his writing on the Civil War. At one point he is conversing with his cousin, Alejandro Cercas who, like Cercas, is not comfortable that his family members supported the "wrong" side:

\begin{abstract}
Alejandro aprovechó mi silencio para explicar: "Mira Javi. Yo nunca quise saber nada de mi familia; de la familia de mi padre, sobre todo, que es la tuya, ya sabes, los que mandaban en el pueblo. Me parecían horribles. Ahora, con la edad, creo que los entiendo mejor, pero..." "Eso es lo que debería intentar yo si contase la historia de Manuel Mena", intervine. "¿El qué?" preguntó Alejandro. "Saber", dije. "No juzgar", añadí. "Entender", aclaré. Y al final concluí: "A eso nos dedicamos los escritores" (p. 162).
\end{abstract}

Cercas's stated intention here not only adheres to both Rieff's and Juliá's inclinations regarding the "duties" of those who write on the Spanish Civil War or any war, but it also serves as an answer to those who might criticize Rieff for his seeming lack of an alternative to the abuses of history. It is not our moral imperative to remember, says Rieff, because that leads us into some dangerous territory with unintended consequences; it is rather our duty to understand.

Juliá is clearly skeptical of cultural studies for the privileging of memory, identity and oppressed groups in an attempt to a counter official history. As his title indicates his book is an elogio (praise) of history in times of memory. Rieff's study is also a "praise", literally (albeit tongue-in-cheek) a "praise of forgetting", forgetting, that is, as a refusal to fall captive to the myths, resentments, voices of victimization, and revenge that come from an active, at times false, memory. Like Juliá, it seems to me that throughout his book, Rieff begs for a consideration of dispassionate and accurate history told from a distance. And Cercas's novels are practical manifestations of this alternative to an overactive historical memory: "To understand... This is what we writers are dedicated to".

Still, there is an important dimension of this discussion that our three critics of historical memory would do well to consider, if not confront head on. I refer to historical understanding (or questioning of that understanding) that arises from insistent interrogation of the memory and articulation of "the Other", a spirit of inquiry that comes out of cultural and post-colonial studies focusing on the subaltern, gender, and race. What of the subaltern voice, the silent voice that thinkers like Gayatri Spivak, ${ }^{12}$ Arundhati Roy, ${ }^{13}$ and Homi Bhabha ${ }^{14}$ have made great strides to vindicate? Or better yet, pointing out those silent voices questions not only the accuracy but the very foundation of recorded history. Indeed

\footnotetext{
${ }^{11}$ Javier Cercas, El monarca de las sombras (Barcelona: Penguin Random House, 2017).

${ }^{12}$ Gayatri Spivak, "Can the Subaltern Speak?" in Rosalind C. Morris (ed.), Can the Subaltern Speak: Reflections on the History of an Idea (New York: Columbia University Press, 2010).

13 Arundhati Roy, Capitalism a Ghost Story (Chicago: Haymarket Books, 2014).

${ }^{14}$ Homi Bhabha, Location of Culture (New York and London, Routledge, 1994).
} 
Spivak's now famous question, "Can the subaltern speak?" is paramount to the discussions and polemics regarding historical memory. It is understandable, if not beneficial, to privilege individual memory of certain situations when the conventional history documents, primary sources, official archives, records compiled by governmental organs or institutions - is faulty? "Faulty" in some cases is a euphemism given the blatant distortions of historical records for a variety of reasons or motivations. In countless cases the individual memory of a witness or a victim of atrocity provides an inroad, particularly in the cases of individuals who are members of a group traditionally marginalized by the society at large. In the case of the Spanish Civil War, the many studies to have emerged relatively recently on women in the War are examples of how and why questioning the conventional wisdom offers a perspective we have not seen. Surely there remain cases of collectivities or groups from whom and about whom we have not heard enough.

Indeed the exclusion of women is still alive. An example is in the very novel that I cited earlier by Cercas, El monarca. In an early chapter he interviews a ninety-year old man from his home town of Ibahernando whose father was taken from his dwelling place and shot. The old man never, or hardly ever spoke of the incident. Cercas, the historianprotagonist of his own novel, goes through verbal contortions to try to get this man to speak openly, but his efforts fall short. The man's daughter, however, tells him several times that while her father has always been tightlipped about the war, her mother, now deceased, had much to say when she was alive. But we readers never find out what the mother said or what she remembered, because Cercas chooses to focus exclusively (in this chapter) on the old man. The wife of El Pelaor remained silent, and Cercas allowed her silence to remain within the realm of the subaltern. Similarly, Santos Juliá questions, perhaps for good reasons, the privileging of marginalized groups, but as a result willful (and at times unconscious) forgetfulness, perhaps this privileging is just what we need for a fuller understanding of what happened. ${ }^{15}$

Rieff, also seems skeptical of what he sees as intense and ultimately vindictive inquiries on the victimization of the losers of historical battles. For example he discusses the heightened insistence on the Shoah or Holocaust as the mother of all atrocities. Citing Margalit and Tony Judt he points out that the sacred place of the Shoah in human memory is losing "resonance" (p. 61). Juliá in a similar vein devotes several pages to the Israeli "Holocaust industry" as it is described in Norman Finkelstein's well known book of the same title, much maligned in the U.S. where the Jewish political scientist argues with a vast array of empirical evidence that the memory of the Holocaust is used to promote Israeli expansion and bombardment of Arab communities.

While not directly pertinent to the historical memory of the Spanish Civil War, I ask readers to consider a work in the line of subaltern studies, published in 2002, that has recently come to my attention. I'm talking about Cultural Trauma: Slavery and the

\footnotetext{
${ }^{15}$ Interestingly, in David Trueba's film adaptation of Cercas's novel, Soldados de Salamina, the protagonist is a woman, a change (adulteration?) that makes for a challengingly different end.
} 
Formation of African American Idenity, by Ron Eyerman. ${ }^{16}$ Eyerman argues in the light of all that has been advanced about historical and or collective trauma (Cathy Caruth is just one example), ${ }^{17}$ and the latency of traumatic events that come back to haunt, in the case of African Americans - and I would argue all descendants of the African diaspora -, the historical trauma is different. It is a unique case. To remember collective trauma is not something you can choose if you are Black; it is with you every day as an element of self, no matter if you recall it or not. In all three of the writers I deal with here (Rieff, Juliá, and Cercas), memory seems to be a matter of choice, an ethical duty, as in "Those who cannot remember..." For African Americans it is impossible to forget; it's constantly there as a quotidian reality. Avoiding or forgetting is not an option.

Focusing on Spain and the Civil War, a historical reality not given enough attention in my view (although there are notable exceptions) is the Moroccan presence in Franco's troops. While not a diaspora in the conventional sense, these moros de Franco left their lands, not as slaves but as recruits. Their difference, their status as other, their identity, depended on something palpable, a remembrance that was always-already in plain view regardless of the awareness of it. A case in point is a gripping poem by Langston Hughes, the famous African American poet who was a journalist reporting from Spain during the war. It is titled "Letter from Spain". ${ }^{18}$ The poetic voice finds a fallen Moroccan soldier who was fighting for "the other side", and interrogates him as he lies dying. Paraphrasing, "Brother", he says, "What are you doing here fighting against yourself?" Unlike Kipling's nationalistic incantation, this poem refers to another kind of historical memory, something impossible to escape: the encounter between the African American diaspora and an imperialist war - that's how Hughes saw the Spanish conflict - that perpetuates the diaspora. Hughes is talking about history repeating itself, but he does so with a de facto awareness that can't be avoided. His encounter has to do with his own historical identity in conjunction with that of the Moroccan.

I read Rieff's book as something of a modest proposal in the vein of Jonathan Swift, an idea to ponder, not necessarily to act upon. Learning from history, understanding memory through the prism of history, its sequences, its complications, ironies, and contradictions is in the long run the ultimate aim of his words regardless of the title of his book. Ironically Praise of Forgetting is not really a praise of forgetting, but a critique of destructive remembrance and of the privileging of the historical self to the detriment of historical understanding. In this sense Rieff's book is a compendium to all the work he has done in defense and benefit of the victims of blind remembrance.

\footnotetext{
${ }^{16}$ Ron Eyerman, Cultural Trauma: Slavery and the Formation of African American Identity (Cambridge, UK: Cambridge University Press, 2002). I would like to thank LaTanya McQueen, a recent creative writing PhD from the University of Missouri, for making me aware of Eyerman's book.

${ }^{17}$ Cathy Caruth, Trauma: Explorations in Memory (Baltimore: Johns Hopkins University Press, 1995).

${ }^{18}$ Langston Hughes, "Letter from Spain" in Edward Mullin, Langston Hughes in the Hispanic World and Haiti (Hamden, CT: Archon Books, 1977).
} 
"Those who cannot remember the past are condemned to repeat it", but those who remember without understanding are equally condemned, and, more important, ill-equipped to forge different outcomes.

Michael Ugarte

Universidad de Missouri-Columbia

ugartem@missouri.edu

Michael Ugarte has written extensively on modern Spain and Spanish culture, the most pertinent for the topic of this essay is Shifting Ground: Spanish Civil War Exile Literature (Durham, N.C.: Duke University Press, 1989). This book was translated into Spanish as Literatura española en el exilio: un estudio comparativo (Madrid: Siglo XXI, 1999.) Presently he is writing a memoir of his mother, Mercedes Precioso, daughter of silver age writer, Artemio Precioso.

Michael Ugarte ha escrito extensamente sobre aspectos variados de la cultura española y la España moderna, siendo su trabajo más representativo desde el punto de vista de este ensayo Shifting Ground: Spanish Civil War Exile Literature (Durham, N.C.: Duke University Press, 1989). Este libro fue traducido al español como Literatura española en el exilio: un estudio comparative (Madrid: Siglo XXI, 1999). Actualmente el autor está escribiendo un libro memorial sobre su madre, Mercedes Precioso, hija del escritor de la Edad de Plata Artemio Precioso.

Fecha de recepción: 19 de mayo de 2017.

Fecha de aceptación: 19 de junio de 2017.

Publicación: 30 de junio de 2017.

Para citar este artículo: Michael Ugarte, "In Praise of Forgetting and the Historical Memory of the Spanish Civil War. Reseña de David Rieff, In Praise of Forgetting: Historical Memory and Its Ironies. New Haven, CT: Yale University Press, 2016, 160 pp.”, Historiografías, 13 (enero-junio, 2017): pp. 146-155.

http://www.unizar.es/historiografias/historiografias/numeros/13/ugarte.pdf 